\title{
Dossiê
}

Partidos políticos, eleições e comportamento político-eleitoral no Brasil

\section{O regime civil-militar e a política local: uma proposta de tipologia para análise de recrutamento e padrões de carreira de prefeitos nomeados no Rio Grande do Sul}

\begin{abstract}
Rafael Machado Madeira
Professor do Programa de Pós-Graduação em Ciências Sociais e coordenador do Centro Brasileiro de Pesquisas em Democracia da PUCRS rafaelmachadomadeira@gmail.com
\end{abstract}

\section{Dirceu André Gerardi}

Doutorando do Programa de Pós-Graduação em Ciências Sociais, pesquisador vinculado ao Centro Brasileiro de Pesquisas

em Democracia da PUCRS

andregerardi3@hotmail.com

\begin{abstract}
Resumo: A designação de "área de segurança nacional" permitiu aos militares o controle sobre a indicação de prefeitos em duas décadas (1966-1985). Ao definir quem receberia as chaves da prefeitura, o regime impacta diretamente a correlação de forças entre lideranças políticas em âmbito local. A perseguição a líderes mais combativos ao regime deixa espaço livre para as lideranças que deram sustentação política ao mesmo. Mas o impacto dos militares na política local não se restringe à exclusão dos "esquerdistas" da cena eleitoral. Seja apoiando uma liderança tradicional em detrimento de outra(s), seja forçando algum tipo de compromisso entre os diferentes grupos, ou ainda patrocinando o ingresso de novas lideranças, o regime teve impacto direto sobre o aumento ou diminuição das chances de manutenção de carreiras políticas ao longo de sua vigência e mesmo após o seu término. Tendo em vista este cenário a pesquisa pretende: 1) identificar o perfil dos nomeados (vínculos anteriores com a política partidária e/ou eleitoral; 2) mensurar até que ponto o regime patrocinou o ingresso de novas lideranças políticas e 3) constatar se estas lideranças tiveram interesse e condições de manter suas carreiras após o término da transição.
\end{abstract}

Palavras-chave: Regime autoritário; Prefeitos nomeados; Carreiras políticas. 
Abstract: The designation of "national security area" allowed the military control over the appointment of mayors in two decades (1966-1985). While determining who would receive the keys to the city hall, the regime impacts directly on the balance of power among political leaders at the local level. The persecution of the most leftist militant leaders gave free space for the supporters of the authoritarian rule. But the impact of the authoritarian regime in local politics was not restricted to the exclusion of the "leftist leaders". By supporting one traditional leadership at the expense of other traditional leadership, by forcing some sort of compromise between different traditional leaderships, or by sponsoring the entry of new leaders, the regime had a direct impact on the chances of maintaining political careers. Given this scenario, the research aims to: 1) identify the profile of the nominees (previous ties to partisan politics and/or elections; 2) measure the extent to which the authoritarian regime sponsored the entry of new political leadership, and 3) see if these leaders were interested and able to maintain their careers even after the political transition.

Keywords: Authoritarian rule; appointed mayors; political careers.

\section{Introdução}

É impossível analisar a história recente do Brasil sem levar em consideração a última experiência autoritária (1964-1985) pela qual passou nosso país. Tal fato pode ser facilmente identificado em diferentes esferas, como, por exemplo, na economia (crescimento econômico associado com o aumento da concentração de renda, da desigualdade social e da inflação), na sociedade civil (repressão e desarticulação de movimentos sociais), bem como na atuação do estado (militarização e cultura de violência policial). A esfera político-partidária não foge à regra. A simples constatação de que o regime criou um sistema bipartidário (que se constituiu na matriz da reorganização do atual multipartidarismo brasileiro) (Madeira, 2006) e patrocinou o ingresso/consolidação de diversas lideranças arenistas (através, por exemplo, dos governos estaduais) demonstra o impacto do regime na esfera político-partidária.

Este artigo pretende elucidar as seguintes questões: os prefeitos nomeados nos municípios considerados área de segurança nacional eram políticos tradicionais ou outsiders? Estes prefeitos tentaram manter suas respectivas carreiras políticas após o final do regime? Em caso afirmativo, eles tiveram êxito em tal empreitada? Diversos estudos demonstraram o impacto da experiência autoritária na esfera política em âmbito nacional (Power, 2000; Madeira, 2006 e 2011; Grimberg, 2009; Jenks, 1979; Carvalho, 2008) e estadual (Madeira, 2002; Oliveira, 2010). Esta análise pretende mensurar o impacto do 
regime militar prioritariamente na dinâmica político-partidária municipal (Madeira \& Gerardi, 2012).

Mais precisamente, o que se busca mensurar é até que ponto o regime civil-militar impactou o processo de recrutamento e de manutenção de carreiras de elites em âmbito local e, principalmente, se este impacto se prolonga após o término do regime. A hipótese a ser testada é a de que também em âmbito municipal as estratégias implementadas pelo regime continuaram impactando o cenário político-eleitoral, mesmo após o seu término, em pelo menos dois aspectos. Por um lado: 1) reforçou a possibilidade de manutenção de carreiras (dado que exclusividade do acesso a incentivos seletivos durante praticamente duas décadas beneficia quadros do partido governista). Por outro lado: 2) o fato da nomeação ser prerrogativa do governo federal permitiu que Brasília reproduzisse nestes municípios a estratégia de patrocínio de "novas" lideranças político-partidárias, assim como ocorre em âmbito estadual (Madeira, 2002).

Toma-se aqui como objeto de análise os padrões de carreira política dos prefeitos nomeados pelo regime militar nas áreas de segurança nacional do estado do Rio Grande do Sul. Esta análise abrange 141 casos que se distribuem em 29 municípios significativamente heterogêneos entre si (ver anexo). Nosso universo de análise compreende municípios grandes (Porto Alegre), médios (Bagé e Uruguaiana) e pequenos (Herval e Vicente Dutra), de todas as regiões do estado e com diferentes perfis socioeconômicos.

O fato de estes municípios terem sido designados "área de segurança nacional" permitiu ao regime o controle sobre a indicação de prefeitos ao longo de duas décadas (1964-1985). Tendo em vista o fato de que o executivo municipal constitui-se no principal posto eletivo em âmbito local, é razoável pressupor que ao definir quem receberia (e por quanto tempo manteria) as chaves da prefeitura, o regime acaba por impactar diretamente na correlação de forças entre tradicionais e novas lideranças políticas em âmbito local. Para além de perseguir, de cassar os direitos políticos, de prender e de condenar ao exílio as lideranças políticas "radicais de esquerda" e mais combativas ao regime, deixando assim espaço livre para as lideranças que apoiaram e deram sustentação política ao mesmo, identifica-se aqui que os militares impactaram diretamente nas disputas entre seus apoiadores. Seja apoiando uma liderança tradicional em detrimento de outra(s), seja forçando algum tipo de compromisso entre os diferentes grupos, seja patrocinando o ingresso de novas lideranças (burocratas sem experiência eleitoral 
anterior), o regime teve impacto direto sobre o aumento ou diminuição das chances de manutenção de carreiras políticas ao longo de sua vigência e mesmo após o seu término.

Busca-se aqui, portanto, explorar uma dimensão ainda pouco analisada do impacto do regime sobre a classe política brasileira - a sua relação com a Arena em âmbito municipal. Mais que o mercado eleitoral, será o regime que exercerá o papel de recrutador e selecionador de lideranças político-partidárias. Esta análise trabalha com dois conjuntos de dados: o primeiro constitui-se em banco de dados de carreira (anterior e posterior ao período) e de recrutamento dos 141 casos analisados; o segundo conjunto de dados corresponde a 35 entrevistas (gravadas em vídeo) realizadas no ano de 2012 em alguns dos municípios analisados.

Além de contribuir para maior compreensão da dinâmica política em um período ainda pouco valorizado pela disciplina, este trabalho tem como objetivo contribuir com os estudos de carreira política ao explorar aqui também um filão muito pouco estudado. Normalmente, estudos de carreira adotam como pressuposto que a política em âmbito municipal é apenas o ponto de partida das mesmas. Isto quando as carreiras já não se iniciam em postos de destaque em âmbito estadual ou mesmo nacional. E são normalmente estes cargos que são utilizados como lócus privilegiado para analisar padrões de carreira política.

Nosso argumento aqui é o de que análises que partam de cargos como deputado estadual, deputado federal, senador, governador, etc. são eficazes para mapear apenas padrões de carreira daqueles que (no início ou ao longo de suas carreiras) conseguiram ultrapassar as fronteiras da política local/municipal, deixando de fora da análise contingentes expressivos de detentores de cargos eletivos.

Ao tomar a política local não como ponto de partida, mas como universo onde muitas carreiras políticas nascem, se desenvolvem e são finalizadas, pretendemos contribuir com a literatura no sentido de aumentar a compreensão acerca de padrões e dinâmicas de funcionamento característicos da elite política brasileira na sua base. 


\section{Recrutamento e carreira dos nomeados: uma proposta de tipologia}

A tipologia proposta para guiar a análise das carreiras dos prefeitos nomeados permite identificar pelo menos oito rotas, resultantes do cruzamento entre dados de recrutamento (família tradicional) e de carreira política (anterior e posterior ao regime). Estas rotas estão estruturadas a partir de diferentes combinações entre três eixos principais: 1) o fato dos nomeados pertencerem ou não a famílias políticas tradicionais; 2) a existência de carreira prévia à nomeação para o cargo de prefeito municipal e 3) a manutenção, ou não, das respectivas carreiras após o final do regime e a normalização do jogo eleitoral nos municípios.

Figura 1 - Tipologia: recrutamento e carreiras políticas

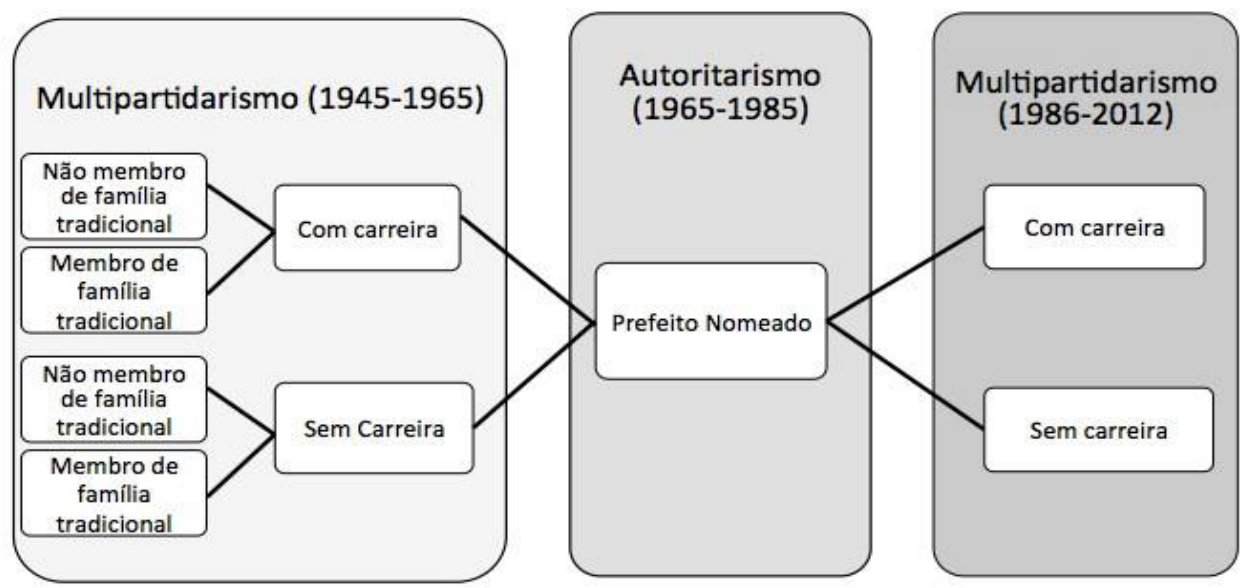

A sobreposição destes três eixos permite a classificação dos nomeados pelo regime em oito rotas diferentes. E será a frequência de casos em cada rota que servirá como parâmetro para mensurar o impacto do regime na configuração das elites políticas locais, bem como no mercado eleitoral pós-regime nos municípios analisados. A tipologia tem como primeiro corte o fato dos nomeados serem (ou não) provenientes de famílias políticas tradicionais. O critério adotado para definir se o nomeado possui família política tradicional é bastante simples: a existência de parente (em primeiro ou segundo graus) que tenha ocupado cargo eletivo antes da sua nomeação à prefeitura. Este critério é passível de crítica (e foi criticado), dado que retira deste grupo, por 
exemplo, nomeados que, eventualmente, tenham sido genros de lideranças políticas tradicionais e que atuaram como herdeiros políticos dos mesmos. Mesmo reconhecendo que tal crítica é procedente, optou-se por manter um critério mais restritivo, uma vez que a escassez de dados torna bastante difícil identificar genros, noras etc.

Define-se aqui por carreira dos nomeados tanto cargos eletivos quanto cargos não eletivos (secretarias municipais e estaduais, postos em estatais, indicação para tribunais etc.) ocupados antes ou após a nomeação. Na segunda parte deste artigo, a análise dos padrões de carreira prévia e posterior ao regime permitirá identificar qual destes dois caminhos se constitui na principal via de continuidade das carreiras analisadas.

Quadro 1 - Tipologia: as oito rotas

\begin{tabular}{cccc}
\hline Rota & Originário de família política & Carreira prévia (1945-1965) & Carreira posterior (1979-2012) \\
\hline 1 & Família tradicional & Com carreira & Com carreira \\
\hline 2 & Família tradicional & Com carreira & Sem carreira \\
\hline 3 & Família tradicional & Sem carreira & Com carreira \\
\hline 4 & Família tradicional & Sem carreira & Sem carreira \\
\hline 5 & Sem família tradicional & Com carreira & Com carreira \\
\hline 6 & Sem família tradicional & Com carreira & Sem carreira \\
\hline 8 & Sem família tradicional & Sem carreira & Com carreira \\
\hline
\end{tabular}

Analisando-se o primeiro ramo da tipologia (nomeados com famílias tradicionais), identifica-se que este se divide entre os nomeados pertencentes a famílias tradicionais que possuíam carreira política prévia à nomeação (1 e 2) e os que ainda não haviam conquistado nenhum cargo eletivo' (3 e 4). As rotas 1 e 3 apontam para uma influência exercida pelo regime sobre a correlação de forças entre seus apoiadores. Neste caso, argumenta-se que o impacto do regime teria sido mais o de reforçar os principais grupos políticos dentre os quadros da Arena do que o de criar/patrocinar novos quadros. As

1 Pode-se argumentar que a classificação dos "com família e sem carreira" sofre de ambiguidade, dado que o fato de serem integrantes de famílias tradicionais tenderia a facilitar, cedo ou tarde, a conquista de mandatos eletivos. Mesmo absorvendo esta crítica, argumenta-se aqui que é impossível prever se os mesmos teriam êxito ao ingressar na competição eleitoral, se não tivessem sido nomeados pelo regime. Por outro lado, pode-se afirmar com maior segurança que o fato de terem iniciado sua carreira política formal já como prefeitos apontados e apoiados pelo regime garantiu o sucesso inicial de suas respectivas carreiras. 
rotas 2 e 4 (sem carreira posterior) reproduzem a mesma dinâmica, mas indicam uma influência menor do regime sobre a correlação de forças dos diferentes grupos que o apoiavam, dado que este apoio não teria sido suficiente para a manutenção destas lideranças após a redemocratização (seja por desistência de concorrer/ocupar cargos, seja pelo insucesso eleitoral).

O segundo ramo é composto pelos nomeados que não provêm de famílias políticas tradicionais. Assim como no caso anterior, este grupo é dividido entre os que possuíam carreira anterior e os que não possuíam. Ao primeiro (rotas 5 e 6), presume-se que possuíam liderança própria, dado que não provinham de famílias tradicionais e já possuíam inserção eleitoral quando da nomeação. O segundo (rotas 7 e 8) permite identificar com maior precisão se existiu no âmbito municipal a reprodução da estratégia implementada pelo regime em nível estadual (Nery, 1975; Madeira, 2002 e 2006), de patrocinar o ingresso na esfera político-partidária de grupos (geralmente ligados à tecnocracia) até então sem experiência partidária.

Com base na maior ou menor frequência de cada grupo, pode-se estabelecer as seguintes linhas interpretativas:

1. Rotas 1 a 6: regime não cria nova elite, mas reforça (1, 3 e 5) carreiras já existentes.

2. Rotas 1 a 4: regime aposta em lideranças herdeiras de capital político familiar (com ou sem carreira política própria).

3. Rotas 5 a 8: regime lança mão de lideranças despossuídas de capital político familiar (com ou sem carreira política própria).

4. Rotas 2, 4, 6 e 8: sejam estas lideranças novas ou antigas, uma maior frequência destas rotas indica menor impacto do regime no processo de transição. Pode-se supor aqui que tal fenômeno ocorra em função de uma "deputação" do mercado eleitoral poliárquico e/ou que as lideranças apoiadas pelo regime não aprenderam a "jogar pelas regras do jogo" e fracassaram - ou não tentaram - na tentativa de manter suas respectivas carreiras após o término do regime.

5. Rotas 1, 3, 5 e 7: indicam que a influência do regime sobre o processo de reconfiguração partidária foi significativa em âmbito local. Efeito de "reserva de mercado" se prolonga para além do regime.

6. Rotas 1 e 2: regime aposta em lideranças tradicionais, já testadas e com bases políticas estabelecidas no período anterior. 
7. Rotas 7 e 8: regime forja o ingresso de novas lideranças (outsiders) em âmbito local com ou sem sucesso (7 e 8, respectivamente).

\section{Quadro 2 - O mapeamento das rotas}

\begin{tabular}{ccccc}
\hline Rota & Originário de família política & $\begin{array}{c}\text { Carreira prévia } \\
\mathbf{( 1 9 4 5 - 1 9 6 5 )}\end{array}$ & $\begin{array}{c}\text { Carreira posterior } \\
\mathbf{( 1 9 7 9 - 2 0 1 2 )}\end{array}$ & Frequência \\
\hline 1 & Família tradicional & Com carreira & Com carreira & 5 \\
\hline 2 & Família tradicional & Com carreira & Sem carreira & 3 \\
\hline 3 & Família tradicional & Sem carreira & Com carreira & 12 \\
\hline 4 & Família tradicional & Sem carreira & Sem carreira & 8 \\
\hline 5 & Sem família tradicional & Com carreira & Com carreira & 14 \\
\hline 7 & Sem família tradicional & Com carreira & Sem carreira & 11 \\
\hline 8 & Sem família tradicional & Sem carreira & Com carreira & 9 \\
\hline
\end{tabular}

O primeiro dado que convém destacar é o que não aparece acima. Do universo de 141 casos, foi possível mapear e classificar com segurança até o presente momento 71 casos, ou seja, a metade do conjunto de prefeitos nomeados no estado. ${ }^{2}$ Feita esta ressalva e retomando as linhas interpretativas estabelecidas anteriormente, uma primeira aproximação aos dados indica que o conjunto dos prefeitos nomeados no Rio Grande do Sul constitui-se em um grupo significativamente heterogêneo, dado que seis dos oito padrões apresentam uma frequência que gira em torno de 10 casos. A única rota que se destaca das demais (rota cinco), com 14 casos, representa 20\% do universo. Nota-se também que com exceção das duas primeiras rotas, a distribuição dos casos é surpreendentemente equilibrada, girando em torno de 11 casos, com os extremos representando um leve desvio para baixo (8) e um para cima (14). Esta frequência significativa e equilibrada em seis das oito rotas já indica de antemão que o peso do regime e o alegado grau de centralização do processo de nomeação em Brasília não significaram

2 Neste estágio da pesquisa, estamos trabalhando no sentido de preencher as lacunas nos 70 casos ainda incompletos em nosso banco de dados, algo que é dificultado pelo número de prefeituras em questão e pelo fato de a maioria dos municípios não possuir dados sistematizados sobre os perfis de seus ex-prefeitos. Encontrar dados vinculados aos períodos anteriores (1945-1965 e 1965-1985) dificulta ainda mais o acesso aos mesmos. 
a eleição de um perfil aplicado a priori para a escolha dos prefeitos (ao menos no que tange às variáveis aqui analisadas).

Articulando os dados a partir do pertencimento, ou não, dos nomeados a famílias políticas tradicionais, chama a atenção que os prefeitos que não possuíam parente com carreira política (rotas 5, 6, 7 e 8) são mais frequentes do que os herdeiros (rotas 1, 2, 3 e 4) de capital político familiar (43 e 28, respectivamente). Tal achado indica que elites políticas locais já tradicionais não foram o único (talvez sequer o principal) lócus de recrutamento.

Para mensurar o peso do regime na disputa pelo poder municipal mesmo após a sua extinção, passa-se agora à leitura dos dados priorizando-se a quarta coluna (carreira posterior). Para tanto, agrupa-se aqui o conjunto de casos anulando as distinções geradas pelo pertencimento a famílias tradicionais e pela existência de carreira anterior. Tal leitura permite identificar que mais da metade dos casos em questão (40 casos) é composta por nomeados que tiveram êxito na manutenção de suas respectivas carreiras (rotas 1, 3, 5 e 7). Por outro lado, o grupo dos que não seguem carreira posterior (rotas 2, 4, 6 e 8) é bastante significativo (31 casos), o que indica que o peso do regime não foi suficiente para garantir a manutenção das carreiras dos prefeitos nomeados.

Até aqui, a heterogeneidade e o equilíbrio da distribuição dos nomeados nos grupos chegam a surpreender e indicam (pelo menos no agregado) que a reserva de mercado que o regime propiciou a seus apoiadores durante sua vigência não teve uma influência determinante na política em âmbito municipal. Deve-se, contudo, chamar a atenção do leitor para o fato de que com estes dados não é possível dividir, no grupo dos sem carreira política posterior, os que fracassaram dos que sequer tentaram continuar atuando na esfera política.

As linhas interpretativas 4 e 5 dão a pista para a leitura dos dados, organizando-os de forma a isolar quatro perfis distintos:

a. Político tradicional: membro de família política tradicional e com carreira política prévia (rotas 1 e 2).

b. Debutante tradicional: membro de família política tradicional, sem carreira política no período anterior (rotas 3 e 4).

c. Político autônomo: sem família política tradicional, mas com carreira política prévia (rotas 5 e 6). 
d. Outsider: sem familiares na política e sem cargos prévios à nomeação para a prefeitura (rotas 7 e 8 ).

Como a primeira leitura dos dados já adiantou, a nomeação de políticos tradicionais e com carreira prévia foi residual no RS. Este primeiro perfil ilustra apenas oito trajetórias dentre as aqui identificadas, número significativamente menor que o dos demais perfis.

O segundo perfil, por exemplo, é composto por 20 casos, o que indica que as famílias já inseridas na política se constituíram em importante fonte de recrutamento de lideranças jovens, mas articuladas com grupos/máquinas político-partidárias pré-existentes. Estes dados permitem levantar a hipótese de que a inserção de jovens lideranças (herdeiras de capital político familiar) foi uma prática significativamente mobilizada na escolha dos nomeados. Não é desprezível também aqui o fator geracional, para explicar a diferença entre estes dois grupos: é razoável pensar que, ao longo de um período de 20 anos, a geração socializada politicamente no período anterior dê espaço para a geração seguinte.

No entanto, quando passamos à análise dos demais perfis, o provável efeito da variável tempo não se mostra com a mesma consistência, dado que o político autônomo (que assim como o político tradicional possui carreira política anterior e sofre a mesma influência do "efeito geracional") se constitui no perfil mais importante e com maior número de casos identificados no agregado: 25 casos. Analisando-se as rotas individualmente, identifica-se que as duas rotas que compõem este perfil estão entre as três rotas mais importantes.

Por fim, identifica-se que os nomeados sem carreira política anterior compõem também um importante nicho de recrutamento, dado que nada menos do que 18 prefeitos não possuíam familiares, ou carreira política no período anterior. A significativa frequência de casos neste perfil indica que também no âmbito municipal ocorre na Arena o ingresso de quadros desvinculados das principais lideranças políticas que formam o partido em cada município (outsiders).

No início deste artigo foi dito que trabalhos anteriores buscaram examinar o surgimento no interior da Arena de um significativo grupo de lideranças sem envolvimento partidário orgânico anterior e com perfil mais tecnocrático. Este ingresso teve nas secretarias de estado uma das principais vias de acesso à política partidária, dado que, após 
certo período em uma secretaria (ou outro cargo de primeiro ou segundo escalão), estes quadros se cacifavam para disputar uma cadeira seja na Câmara dos Deputados, seja na Assembleia Legislativa do seu estado. Estudos anteriores identificam que o ingresso destes quadros se torna mais frequente na segunda metade do período, ao menos em âmbito estadual (Madeira, 2002 e 2006; Nery, 1975). Distribuindo-se os 18 casos deste grupo ao longo do período analisado, identifica-se que na primeira década apenas seis outsiders foram nomeados, ao passo que na segunda, 12 outsiders, dois terços do total, ascenderam ao posto de prefeito municipal.

A tipologia proposta para mapear os padrões de recrutamento e de carreira política dos prefeitos nomeados no Rio Grande do Sul indica até aqui uma significativa heterogeneidade deste grupo. A significativa frequência de casos em seis das oito rotas e em três dos quatro perfis atesta tal heterogeneidade. Por fim, destaca-se que esta heterogeneidade é explicada pela presença quase equitativa do debutante tradicional, do político autônomo e do outsider.

\section{Radiografia das carreiras políticas: peso de cargos eletivos e não eletivos na construção das carreiras dos prefeitos nomeados}

A partir do mapa geral apresentado, pretende-se nesta segunda parte do artigo destrinchar e detalhar mais os dados de carreira dos prefeitos para que se possa identificar se os mesmos se caracterizam majoritariamente pela presença em postos eletivos, postos não eletivos, ou se existe um equilíbrio entre os mesmos. Também se pretende mensurar se existe diferença nesta correlação de cargos entre os períodos anterior e posterior ao regime.

Cabe chamar a atenção do leitor para o fato de que somente se considerara que o nomeado possui carreira política via postos eletivos se o mesmo tiver sido eleito. Isto é, adota-se aqui um critério conservador (restritivo) para se classificar o prefeito nomeado como possuidor de carreira política. Não basta ao nomeado ter sido filiado ou ter concorrido a cargo eleitoral, dado que o insucesso na eleição (por definição) não permite que o mesmo desenvolva sua carreira política (ao menos pela via eleitoral).

Dentre os principais objetivos de se analisar a presença de carreira política prévia/posterior estão: 1) identificar o grau de envolvimento dos prefeitos nomeados com 
partidos, lideranças e máquinas político-partidárias anteriores ao regime; 2) mensurar tanto a importância de possuir carreira política própria para ser escolhido prefeito quanto a influência de ter sido prefeito nomeado enquanto agente potencializador das chances de manutenção de carreira política no período pós-redemocratização.

A opção por não considerar apenas a filiação partidária ou candidaturas não exitosas como carreira política dificulta atingir o primeiro objetivo, dado que encontramos casos de prefeitos que possuíam vínculos estreitos, sólidos e longevos com seus respectivos partidos, lideranças, ou com máquinas político-partidárias no período anterior, mas que constam no banco de dados como despossuídos de carreira. Um exemplo de herdeiro de capital político "não formal" que foge à classificação aqui adotada pode ser identificado neste trecho do depoimento de um dos prefeitos entrevistados. Apesar de ser herdeiro de estancieiros detentores de um capital político e familiar de peso no município e na região, o fato de este prefeito ter sido nomeado e de nenhum parente próximo ter ocupado cargo eletivo formal faz com que o mesmo seja classificado como não oriundo de família política tradicional.

Entrevistador: O seu pai... Na família do seu pai e de sua mãe existia algum político? Os irmãos deles, da sua mãe e do lado do seu pai eram políticos? Como que funcionava isso?

Entrevistado: Do lado do meu pai, o meu avô paterno chamava-se [...] e era cognominado General [...] porque participou da revolução de 1893 e, quando foi na revolução de 1923, ele montou um exército próprio, Jum exército de 700 a 900 homens à custa dele pra pelear nessas coxilhas do Rio Grande contra, na época, o governador Borges de Medeiros. [...]

[...] Então ficou um homem, não é... Muito autêntico e ao mesmo tempo muito importante na região.

Por outro lado, pelo lado da minha mãe não tem ninguém a ver com a vida política pública. Mas o meu avô, que era um fazendeiro muito forte e de ideias muito claras ele... Ele era fanático pelo parlamentarismo e bancou a suas expensas o Partido Libertador durante muito tempo.

Inclusive quando o Presidente Getúlio Vargas se "deshouve" com um grupo político do Rio Grande do Sul, do qual o líder era Raul Pilla... O meu avô... O Raul Pilla teve que deixar o país. Ficou dois anos fora do país; tava perseguido pelo Governo Federal e foi para a fazenda do meu avô no Uruguai. Depois, foi morar na propriedade do meu avô em Montevidéu.

Então, pelos dois lados eu tenho alguma coisa, mas o meu lado forte, digamos, é o lado paterno [...]. (Entrevista 27, concedida em 22/11/2012) 
A tipologia não capta esta influência, dado que, ao invés de postos formais, são os vínculos de amizade, as relações de compadrio e os interesses setoriais que se constituem neste caso no principal capital político do entrevistado. Embora não convertida em capital eleitoral, a influência política "não formal" dos dois ramos da família deste entrevistado no município, que se dá a partir da reconversão de capital econômico e de capital social (prestígio, honra etc.), é inconteste.

Por outro lado, tal critério confere à análise maior precisão quando se busca mensurar a liderança eleitoral exercida pelos nomeados antes e depois da nomeação (objetivo número 2). Ao se excluir os nomeados que apenas se filiaram a partidos, mesmo não ocupando cargos eletivos (ou disputando-os sem sucesso), e ao incluir nesta categoria somente aqueles que passaram pelo crivo das urnas, sendo bem-sucedidos no teste eleitoral, a análise se torna também mais precisa.

Entrevistador: Eu queria perguntar pro senhor: depois que o senhor deixou então de ser prefeito, o que o senhor fez? No caso a gente viu que o senhor foi candidato em 88 a prefeito né, foi candidato em 92, e depois disso...

Entrevistado: E depois disso eu concorri a vereador e também não me elegi.

Entrevistador: Concorreu a vereador... Pelo PP?

Entrevistado: Pelo PP.

Entrevistador: Qual foi o ano que o senhor concorreu?

Entrevistado: Foi em 96. Mas fui secretário depois, dois anos, da agricultura.

Entrevistador: E depois de 2006?

Entrevistado: De 2006, 2007 e 2008 fui secretário.

(Entrevista 31, concedida em 10/12/2012).

Este relato ilustra de forma clara o contexto em questão, em que um ex-prefeito tenta, mas não obtém êxito em dar continuidade a sua carreira política via postos eletivos, dado que o mesmo concorre e perde eleições para prefeito e vereador em três oportunidades. Casos como este indicam que o fato de ter sido nomeado não é garantia de sucesso eleitoral posterior.

Recuperando o que foi afirmado no início deste artigo, tal relato é importante também por permitir chamar a atenção para a relevância de se desmembrar o que se define por carreira política em dois grupos: postos eletivos e postos não eletivos. Para além de postos eletivos, o período na prefeitura pode permitir aos seus ocupantes estabelecer e/ ou fortificar vínculos e redes de contato que serão estratégicos para a carreira posterior 
destes agentes. Podendo, assim, abrir portas para um leque variado de posições que dependem de indicação de governantes nos três poderes, nos três níveis da federação, em empresas estatais etc. Como esta é uma via fundamental de acesso e manutenção de carreiras políticas, o seu mapeamento e mensuração também é objetivo da presente análise. No caso do prefeito em questão, a ocupação de postos no primeiro escalão do governo municipal em diferentes administrações exemplifica esta questão.

Quadro 3 - Carreira anterior (1945-1965)

\begin{tabular}{|c|c|c|c|c|c|c|}
\hline & \multicolumn{3}{|c|}{ Posto eletivo } & \multicolumn{3}{|c|}{ Posto não eletivo } \\
\hline & Casos & $\%$ & \%válido & Casos & $\%$ & \% válido \\
\hline Sim & 42 & 29,7 & 36,5 & 22 & 15,6 & 22,2 \\
\hline Não & 73 & 51,7 & 63,5 & 77 & 54,6 & 77,8 \\
\hline $\mathrm{NI}$ & 26 & 18,4 & --- & 42 & 29,7 & --- \\
\hline Total & 141 & 100 & 100 & 141 & 100 & 100 \\
\hline
\end{tabular}

Ao se desagregar os dados referentes à carreira política anterior dos nomeados, pode-se ter a dimensão da relevância de cada grupo de cargos na manutenção das carreiras dos futuros prefeitos. Tomando-se como critério de mensuração a ocupação de postos no período anterior, identifica-se que no conjunto os prefeitos nomeados se caracterizam por uma reduzida participação. O contingente de nomeados sem passagem em cada grupo é claramente majoritário, chegando a quase $80 \%$ dos casos válidos no que tange aos postos não eletivos.

\section{Quadro 4 - Cruzamento: eletivos e não eletivos (1945-1965)}

\begin{tabular}{|c|c|c|c|c|c|}
\hline & \multicolumn{4}{|c|}{ Posto não eletivo } & \multirow{2}{*}{ Tota } \\
\hline & & Sim & Não & NI & \\
\hline \multirow{4}{*}{ Posto eletivo } & Sim & 6 & 25 & 11 & 42 \\
\hline & Não & 16 & 52 & 5 & 73 \\
\hline & $\mathrm{NI}$ & 0 & 0 & 26 & 26 \\
\hline & Total & 22 & 77 & 42 & 141 \\
\hline
\end{tabular}


No quadro anterior pode-se identificar a frequência de nomeados que possuem passagem por postos eletivos e não eletivos separadamente. Agora, o objetivo é cruzar os dois grupos para estabelecer a distinção entre os que não tinham nenhuma experiência, os que possuíam carreira exclusivamente eletiva, exclusivamente não eletivas e os que possuíam carreiras mistas quando foram nomeados. Destaca-se do quadro acima que em apenas seis oportunidades identificam-se nomeados com carreiras marcadas pelo trânsito entre os dois grupos. Destaca-se, ainda, a importância do grupo formado por nomeados que possuíam apenas cargos não eletivos e, por fim, constata-se novamente aqui a relevância do grupo dos nomeados sem passagem por nenhum cargo político, dado que este grupo é mais numeroso que a soma dos três grupos com experiência prévia. Este dado é relevante, uma vez que o exercício do mandato na prefeitura confere aos dois últimos grupos citados a sua primeira experiência no executivo municipal, sem ter passado pelo crivo do eleitor. Isto é, quando assumiram a prefeitura, 68 nomeados (de um total de 99 casos mapeados) nunca haviam tido a experiência de ganhar uma eleição.

Quadro 5 - Carreira posterior (1979-2012)

\begin{tabular}{|c|c|c|c|c|c|c|}
\hline & \multicolumn{3}{|c|}{ Posto eletivo } & \multicolumn{3}{|c|}{ Posto não eletivo } \\
\hline & Casos & $\%$ & \% válido & Casos & $\%$ & \% válido \\
\hline Sim & 43 & 30,5 & 41,3 & 37 & 26,2 & 39,8 \\
\hline Não & 61 & 43,2 & 58,7 & 56 & 39,7 & 60,2 \\
\hline $\mathrm{NI}$ & 37 & 26,2 & --- & 48 & 34 & --- \\
\hline Total & 141 & 100 & 100 & 141 & 100 & 100 \\
\hline
\end{tabular}

O mesmo padrão verificado nos quadros precedentes se repete no período posterior à passagem pela prefeitura, dado que também neste período os grupos dos que não ocuparam cargos (eletivos e não eletivos) são os que apresentam as maiores frequências. Mais uma vez, identifica-se que a maioria não segue carreira política posterior, seja por abandonar a atividade política, seja por não obter êxito eleitoral no período pós-redemocratização.

A análise das entrevistas indica, para além do fracasso eleitoral, algumas pistas para explicar a baixa frequência de manutenção de carreiras: 1) o retorno de empresários/ agricultores as suas atividades na iniciativa privada e 2) a aposentadoria, ou o retorno de 
militares "sem o cacoete para a política" à caserna após o exercício dos mandatos. No que diz respeito à primeira razão, contudo, o alegado retorno às atividades privadas pode também servir para encobrir e justificar tal afastamento. Para sanar esta dúvida, deve-se empreender análise mais detalhada de cada contexto municipal (caso a caso). Tal empreitada foge ao escopo do trabalho neste momento, mas será realizada em trabalhos futuros.

Quadro 6 - Cruzamento: eletivos e não eletivos (1979-2012)

\begin{tabular}{|c|c|c|c|c|c|}
\hline \multirow{6}{*}{ Posto eletivo } & \multicolumn{4}{|c|}{ Posto não eletivo } & \multirow[t]{2}{*}{ Total } \\
\hline & & Sim & Não & NI & \\
\hline & Sim & 21 & 11 & 11 & 43 \\
\hline & Não & 12 & 43 & 6 & 61 \\
\hline & $\mathrm{NI}$ & 4 & 2 & 31 & 37 \\
\hline & Total & 37 & 56 & 48 & 141 \\
\hline
\end{tabular}

Mais uma vez os dados deste período desenham um contexto marcadamente semelhante ao do período anterior. Assim como o trecho de entrevista citado acima, os dados aqui também indicam que mesmo tendo usufruído com exclusividade dos benefícios (incentivos seletivos - Panebianco, 2005) do controle exclusivo sobre o executivo municipal durante duas décadas, os quadros da Arena (então, já majoritariamente no PDS) tiveram dificuldades para enfrentar o processo de reabertura do mercado eleitoral e de reincorporação de lideranças "de esquerda" à disputa pelo executivo via voto. Tais dados refutam a hipótese de que este controle sobre o executivo tenha garantido aos quadros do PDS a continuidade de suas respectivas carreiras políticas.

\section{Quadro 7 - Familiar na política}

\begin{tabular}{cccc} 
& \multicolumn{3}{c}{ Família política } \\
\cline { 2 - 4 } & Casos & $\%$ & \% válido \\
\hline Sim & 34 & 24,1 & 39,5 \\
\hline Não & 52 & 36,9 & 60,5 \\
\hline NI & 55 & 39 & --- \\
\hline Total & 141 & 100 & 100
\end{tabular}


Por fim, a distribuição dos nomeados entre os que possuíam e os que não possuíam familiares detentores de cargos políticos é um pouco mais equilibrada, embora ainda chame a atenção o fato de que o maior grupo é composto pelos prefeitos sem familiares na política. Tal achado pode ser explicado pelo caráter restritivo adotado nesta análise para incluir casos neste grupo, mas também reflete cenários que aparecem com frequência nas entrevistas realizadas: a decisão explícita de indicação de quadros sem qualquer envolvimento, experiência, ou traquejo eleitoral. Quadros estes muitas vezes desvinculados das principais lideranças da Arena no município (via de regra os principais postulantes ao cargo).

\section{Desconstrução/reconstrução dos pressupostos da análise e definição da agenda para a continuidade da pesquisa}

Retomando as proposições levantadas como hipótese, constata-se que a primeira proposição foi apenas parcialmente confirmada, uma vez que o exercício do poder por duas décadas não garantiu êxito na continuidade de carreira dos quadros da Arena. Já a segunda proposição, parece mais plausível em função do contingente expressivo de prefeitos nomeados sem carreira política prévia e sem familiares que tenham ocupado cargos políticos (eletivos e não eletivos). Tais achados confirmam que elites partidárias não foram o único lócus de recrutamento utilizado. Mas problematizam um dos pressupostos da construção da própria hipótese: confirmar como dada que a indicação era definida sempre a partir de um mesmo procedimento.

A riqueza de informações extraída das entrevistas realizadas com 35 dos prefeitos nomeados permite identificar contextos significativamente distintos que marcaram as escolhas e disputas pela nomeação. De um lado, identifica-se uma diversidade muito grande no que tange à realidade de cada município (que engloba desde a capital até um conjunto significativo de pequenos municípios - isolados no interior do estado, localizados em região de fronteira e/ou em pontos estratégicos como o porto de Rio Grande), de outro lado, existe o procedimento que em tese normatizaria a escolha (elaboração de lista tríplice pelo diretório municipal da Arena, encaminhada ao governador, que faria a indicação do escolhido para passar pelo crivo de Brasília). 
O fato de a palavra final estar em Brasília confere, teoricamente, possibilidade de uniformizar as escolhas realizadas. Contudo, os relatos deixam claro que paralelo ao protocolo, havia uma sobreposição de dinâmicas que iam muito além das diferenças existentes entre os municípios, como, por exemplo: 1) a correlação de forças em âmbito municipal, que muitas vezes definiu a escolha; 2) em outros casos, os vínculos políticos e/ou de amizade com deputados (estaduais e/ou federais), ministros, militares locados em posições estratégicas e até mesmo com o governador, ou com o presidente da República é que são fundamentais; 3) identificaram-se casos em que a definição veio direto da capital, por decisão do governador; e 4) casos em que tal decisão foi tomada em Brasília. Nestes dois últimos cenários, muitas vezes o escolhido sofria resistência por parte das elites locais da Arena.

Muitas vezes, em um mesmo município o processo de indicação era definido com base em mais de uma das variáveis levantadas acima, como se pode identificar claramente nos relatos que seguem:

Entrevistado: Visse... O Pires era conselheiro do Tribunal de Contas do Estado. Então o pessoal queria uma administração inovadora na fronteira, então escolheram. [...] E aí o Pires me procurou, vendo se eu poderia ajudá-lo. Aí eu falei: "Olha, Pires, eu posso te ajudar, mas tem algumas condições. A principal é a seguinte, não ganho nada, não quero emprego, mas o que tu precisar de mim eu te ajudo e pego firme contigo".

E ele foi me usando muito e eu fui me entrosando muito e nesse tempo o Presidente Médici era presidente; Foi quem nomeou ele e, terminou que os pleitos de Bagé, esses, às vezes o Pires me mandava para eu tratar porque eu ficava hospedado com o Presidente e tinha muita facilidade. As verbas finais para esse grande... Presidente Médici... O ginásio de esportes... A gente foi várias vezes a Braślia para liberar. Então, eu fui usado entende? De bom gosto. De muito bom gosto, pelo Pires para ajudar Bagé.

E aí claro, teu nome aparece... Começa todo mundo a te conhecer... Eu fiquei também muito amigo do João Figueiredo por causa do Presidente Médici, em Porto Alegre, quando ele era apenas General de Exército.

Resultado, depois que o Presidente Médici saiu do poder... Que foi o Presidente Geisel... Eu mantive sempre, com o Figueiredo, uma aproximação muito grande porque ficamos muito amigos e gostávamos das mesmas coisas, de cavalo, de mate... Então eu passei a ir muito a Brasília e ia lá para a Granja do Torto. [...]

No outro dia o Figueiredo disse: "O que tu quer do governo? Tu tem que vir pra cá comigo". Eu disse: "Olha, Presidente, vamos olhar bem nos olhos... Eu não venho para cá! Eu não estou interessado em nada daqui. Não faz a minha cabeça. Eu tenho outra vida, tô bem na vida, tô criando meus filhos em uma cidade do interior, que é muito mais fácil; não tenho nenhum atrativo para vir pra cá, a não ser a sua amizade, 
mas daqui a quatro anos acaba o seu mandato e, se eu vier pra cá, quando eu voltar não encontro mais o que é meu. Eu não posso abandonar o que é meu".

"Mas tu é difícil..." Aquela história toda... Resultado; ele bateu na mesa: "Então tu vai ser o prefeito de Bagé".

"Tá. Se eu não tiver que sair de lá, tudo bem." E eu terminei prefeito assim.

[...] Por isso que eu caí de prefeito... Eu não tinha nada a ver com isso, nada, nada, nada a ver... (Entrevista 27, concedida em 22/11/2012).

No caso do município em questão, o fato de o mesmo ser terra natal de um dos presidentes do período de exceção (Garrastazu Médici) constitui-se em fator determinante para entender os processos de escolha dos nomeados. O relato a seguir também indica que em um mesmo município a correlação de forças de cada contexto (quem eram os pretendentes, quais eram os seus principais trunfos, qual era o grau de interesse dos governos estadual e federal no município etc.) faz com que cada município possa ser comparado a um tabuleiro de xadrez, com as peças em constante movimento e em que cada escolha é resultado de diferentes disposições das peças no tabuleiro.

Entrevistador: Então, um dos inícios da sua carreira política foi dentro da administração a convite do Capitão Zoé, é isso?

Entrevistado: Exatamente, a convite.

Entrevistador: Qual era a sua atividade lá?

Entrevistado: A minha atividade era de secretário da administração. O Capitão Zoé veio para cá nomeado, ele veio de Porto Alegre, era da brigada militar, capitão da brigada. E ele veio pra cá em fevereiro de 69 por indicação do Peracchi Barcelos que era o governador na época, Walter Peracchi Barcelos e o Peracchi também era da brigada.

Entrevistador: Esse foi escolhido direto pelo governador então? Não teve reunião do partido aqui e nada?

Entrevistado: Esse foi direto de cima. Acontece o seguinte, houve aqui uma série de reuniões, eu até nem participei dessas reuniões, de pessoas pretendentes a prefeito.

Entrevistador: Isso na época do Zoé?

Entrevistado: Não, antes de ser nomeado o Zoé. Tinha o Barbieri, tinha o Clemente Santignon, era um deles, tinham outros candidatos que queriam ser a todo trapo prefeito nomeado. Mas como houve uma batalha em Porto Alegre e cada um ia lá: "eu quero ser", "eu quero ser" e "eu quero ser". O governador não gostou dessa intriga interna que se formou por causa dessa ganância de querer ser, o governador chamou o Capitão Zoé com quem ele tinha bastante intimidade e convidou ele para ser prefeito, nomeou ele para ser prefeito [...] E aí no começo deu uma revolta daqueles que queriam ser porque veio um prefeito de fora, mas eu posso Ihe dizer que o Capitão Zoé foi um 
baita prefeito, um homem sério, um homem íntegro, um homem honesto a toda prova, eu trabalhei com ele seis anos e meio praticamente. [...]

Daí fiquei com o Capitão Zoé de 69, 29 de março de 69, nunca me esqueço, eu assumi como secretário até julho, se não me engano, de 75 quando daí então foi nomeado o Clemente Santinon e eu continuei como secretário do Clemente também. Moral da história: eu fiquei doze anos e oito meses como secretário da administração direto, dos dois prefeitos. E aí fui nomeado prefeito em 81. [...]

Entrevistado: [...] na verdade acontece o seguinte: a norma para a nomeação de prefeitos nas áreas de segurança era a indicação, a exigência do governo, de lista tríplice de nomes para que o governo escolhesse um nome desses dos três para ser nomeado. E realmente essa lista foi encaminhada daqui, eu disse pro prefeito Clemente, que mais insistiu pra que eu fosse prefeito, eu disse: "Clemente, eu aceito colocar meu nome, agora, se é pra mim estar concorrendo e fazer rixa política como já deu no passado antes do Capitão Zoé assumir, eu prefiro ficar fora, não quero, prefiro que não" (Clemente responde): "Não, eu já falei com o governador, o governador me disse que é pra mim trazer os três nomes lá porque a norma indica, mas você vai ser o nomeado".

(Entrevistado finaliza): "Nessas condições eu aceito" (Entrevista 10, concedida em 24/10/2012).

Tal relato explícita que em um primeiro contexto o nomeado "veio de cima", por escolha do governador. E o entrevistado veio a ser nomeado somente após 12 anos como secretário municipal. Este é justamente o trunfo que o entrevistado relata como sendo fundamental para a sua escolha: seu domínio (expertise) sobre a máquina burocrática e administrativa da prefeitura e seu conhecimento acerca da vida do município. Mas, como o depoimento indica, talvez estes atributos não seriam suficientes se não houvesse também a intermediação e o apoio do prefeito que saía do cargo junto ao governador do estado.

Este trabalho ainda está em desenvolvimento. Suas próximas etapas envolvem o aprimoramento da presente análise em pelo menos três frentes: 1) a busca pelos dados de carreira e de parentesco ainda ausentes; 2) o aprimoramento e discussão de potencialidades e limites dos critérios definidos para construção da tipologia proposta e 3) análise mais aprofundada e sistemática das entrevistas. A articulação e aprimoramento destas diferentes ferramentas analíticas representam um significativo desafio. Desafio este cujo enfrentamento gera muitas dificuldades, mas que pode render bons frutos para se lançar luzes sobre um período particular de nossa história e tão pouco estudado no âmbito da disciplina. Por fim, e independentemente do recorte temporal desta 
pesquisa, busca-se avançar no sentido de compreender melhor a articulação entre dinâmicas políticas que caracterizam as três esferas de governo: municipal, estadual e nacional.

\section{Referências bibliográficas}

CARVALHO, Alessandra. (2008). Elites políticas durante o regime militar: um estudo sobre os parlamentares da Arena e do MDB (Tese: Programa de Pós-Graduação em Sociologia e Antropologia - UFRJ). Rio de Janeiro.

GRINBERG, Lúcia. (2009). Partido político ou bode expiatório: um estudo sobre a Aliança Renovadora Nacional (Arena), 1965-1979. Rio de Janeiro: Mauad X.

JENKS, Margaret S. (1979). Political Parties in Authoritarian Brazil. Ph.D. Dissertation, Duke University.

MADEIRA, Rafael Machado. (2002). ARENA ou ARENAs? A coesão partidária da legenda do regime em três estados brasileiros. (Dissertação de Mestrado). Porto Alegre: PPG - Ciência Política: UFRGS.

. Vinhos antigos em novas garrafas: a influência de ex-arenistas e ex-emedebistas no atual multipartidarismo brasileiro. (Tese de Doutorado) Porto Alegre: PPG-Ciência Política: UFRGS.

. (2011), A atuação de ex-arenistas e ex-emedebistas na Assembleia Nacional Constituinte. Revista Brasileira de Ciências Sociais, Volume 26, Número 77. São Paulo: 189-203.

; GERARDI, Dirceu A. (2012). Descomprimindo tendências: os embates intrapartidários no interior da ARENA e MDB em eleições municipais gaúchas (1968-1976). In: CUARTO CONGRESSO URUGUAYO DE CIENCIA POLITICA. Montevideo: Uruguai.

NERY, Sebastião. (1975). As 16 derrotas que abalaram o Brasil. Rio de Janeiro: Livraria Francisco Alves.

OLIVEIRA, Ueber J. de. (2010). Considerações acerca da configuração político-partidária do Espírito Santo no contexto do regime militar: um estudo regional das disputas eleitorais entre Arena e MDB (1964/65-1979). I/ Seminário Nacional de Sociologia e Política Curitiba: UFPR. 
PANEBIANCO, Angelo. (2005). Modelos de Partido. Organização e poder nos partidos políticos. São Paulo: Martins Fontes.

POWER, Timothy J. (2000). The political right in postauthoritarian Brazil. Elites, institutions and democratization. Pennsylvania State University Press.

\section{Anexo I - Dados dos prefeitos nomeados no Rio Grande do Sul}

\begin{tabular}{|c|c|c|c|c|c|c|c|c|c|c|}
\hline Nome & Município & $\begin{array}{l}\text { Ano } \\
\text { início }\end{array}$ & $\begin{array}{l}\text { Ano } \\
\text { final }\end{array}$ & Entrada & $\begin{array}{l}\text { Eleito } \\
45 / 65\end{array}$ & $\begin{array}{l}\text { Bur. } \\
45 / 65\end{array}$ & $\begin{array}{l}\text { Eleito } \\
79 / 12\end{array}$ & $\begin{array}{l}\text { Bur. } \\
79 / 12\end{array}$ & $\begin{array}{l}\text { Fam. } \\
\text { Pol. }\end{array}$ & Rota \\
\hline $\begin{array}{l}\text { Albano Emílio } \\
\text { Jung }\end{array}$ & Alecrim & 1969 & 1973 & Nomeado & Sim & & & & & \\
\hline Dário A. Schaedler & Alecrim & 1983 & 1986 & Nomeado & & & Sim & & Sim & 1 ou 3 \\
\hline José E. Rauber & Alecrim & 1964 & 1969 & Eleito & Sim & & & & & \\
\hline João O. Schaedler & Alecrim & 1973 & 1983 & Nomeado & Sim & & & & & \\
\hline $\begin{array}{l}\text { Eugênio O. } \\
\text { Rockenba }\end{array}$ & Alecrim & 1964 & 1969 & Eleito & Sim & & & & & \\
\hline Lauro Aluísio Rech & Alecrim & 1973 & 1983 & Nomeado & & & & & & \\
\hline Carlos S. Azambuja & Bagé & 1979 & 1985 & Nomeado & Não & Não & Sim & Sim & Sim & 3 \\
\hline José W. Barcellos & Bagé & 1964 & 1969 & $\begin{array}{l}\text { Eleito pela } \\
\text { CV }\end{array}$ & Não & Não & Não & Não & & 4 ou 8 \\
\hline $\begin{array}{l}\text { Carlos M. M. } \\
\text { Silveira }\end{array}$ & Bagé & 1975 & 1975 & Interino & Sim & Não & Não & Não & Sim & 2 \\
\hline $\begin{array}{l}\text { Antônio C. S. } \\
\text { Pires }\end{array}$ & Bagé & 1971 & 1975 & Nomeado & Não & Sim & Não & Sim & Não & 5 \\
\hline Darci Barcellos & Bagé & 1964 & 1969 & $\begin{array}{l}\text { Eleito pela } \\
\text { CV }\end{array}$ & & & & & & \\
\hline Luiz Simão Kalil & Bagé & 1978 & 1979 & Interino & Sim & Não & Sim & Sim & Sim & 1 \\
\hline $\begin{array}{l}\text { Cel. Washington } \\
\text { Bandeira }\end{array}$ & Bagé & 1969 & 1971 & Nomeado & Não & Não & Não & Não & Sim & 4 \\
\hline Camilo Moreira & Bagé & 1975 & 1978 & Nomeado & Sim & Sim & Sim & Sim & Não & 5 \\
\hline $\begin{array}{l}\text { Cláudio B. } \\
\text { Schultz }\end{array}$ & Canoas & 1984 & 1985 & Interino & Não & Sim & & Sim & & 1 ou 5 \\
\hline $\begin{array}{l}\text { Luiz Jeronymo } \\
\text { Busato }\end{array}$ & Canoas & 1978 & 1978 & Nomeado & & & & Sim & Não & 5 ou 7 \\
\hline $\begin{array}{l}\text { Ney de M. } \\
\text { Calixto }\end{array}$ & Canoas & 1983 & 1984 & Interino & Não & Não & Sim & & Sim & 3 \\
\hline $\begin{array}{l}\text { Geraldo G. } \\
\text { Ludwig }\end{array}$ & Canoas & 1973 & 1979 & Nomeado & & & & & & \\
\hline Hugo S. Lagranha & Canoas & 1969 & 1971 & Nomeado & Sim & Sim & Sim & Não & Não & 5 \\
\hline $\begin{array}{l}\text { Oswaldo C. } \\
\text { Guindani }\end{array}$ & Canoas & 1979 & 1983 & Nomeado & & & & & & \\
\hline
\end{tabular}




\begin{tabular}{|c|c|c|c|c|c|c|c|c|c|c|}
\hline Nome & Município & $\begin{array}{l}\text { Ano } \\
\text { início }\end{array}$ & $\begin{array}{l}\text { Ano } \\
\text { final }\end{array}$ & Entrada & $\begin{array}{l}\text { Eleito } \\
45 / 65\end{array}$ & $\begin{array}{l}\text { Bur. } \\
45 / 65\end{array}$ & $\begin{array}{l}\text { Eleito } \\
79 / 12\end{array}$ & $\begin{array}{l}\text { Bur. } \\
79 / 12\end{array}$ & $\begin{array}{l}\text { Fam. } \\
\text { Pol. }\end{array}$ & Rota \\
\hline Daniel Cruz Costa & Canoas & 1971 & 1973 & Nomeado & Não & Não & Não & Não & Não & 8 \\
\hline Francisco Biazus & Canoas & 1985 & 1985 & Interino & Não & Não & Não & Sim & Não & 7 \\
\hline Aparício Piccinin & Catuípe & 1969 & 1977 & $\begin{array}{l}\text { Eleito, } \\
\text { depois } \\
\text { nomeado }\end{array}$ & Sim & Não & Sim & Não & Não & 5 \\
\hline $\begin{array}{l}\text { Taurino C. } \\
\text { de Souza } \\
\text { (vice-prefeito) }\end{array}$ & Catuípe & 1969 & 1977 & $\begin{array}{l}\text { Eleito, } \\
\text { depois } \\
\text { nomeado }\end{array}$ & Sim & & & & Sim & 1 a 4 \\
\hline $\begin{array}{l}\text { Constantino } \\
\text { Demeneghi }\end{array}$ & Catuípe & 1977 & 1982 & Nomeado & Não & Não & Não & Não & Não & 8 \\
\hline Luiz F. Menegon & Catuípe & 1977 & 1982 & Nomeado & Não & Não & Sim & Sim & Não & 7 \\
\hline $\begin{array}{l}\text { Pedro H. } \\
\text { Hoffmann }\end{array}$ & Crissiumal & 1964 & 1969 & $\begin{array}{l}\text { Eleito, } \\
\text { depois } \\
\text { nomeado }\end{array}$ & Sim & Não & Não & Não & Não & 6 \\
\hline Carlos Willy Grun & Crissiumal & 1980 & 1985 & Nomeado & Não & Sim & Não & Sim & Não & 5 \\
\hline Pedro O. Scheid & Crissiumal & 1975 & 1980 & Nomeado & Sim & Não & Não & Não & Não & 6 \\
\hline Benno Bender & Crissiumal & 1969 & 1975 & Nomeado & Sim & Não & Sim & Não & Não & 5 \\
\hline $\begin{array}{l}\text { José C. Coelho } \\
\text { Leal }\end{array}$ & $\begin{array}{l}\text { Dom } \\
\text { Pedrito }\end{array}$ & 1975 & 1985 & Nomeado & Não & Não & Sim & Sim & Sim & 3 \\
\hline $\begin{array}{l}\text { Crispim C. da } \\
\text { Cruz }\end{array}$ & $\begin{array}{l}\text { Dom } \\
\text { Pedrito }\end{array}$ & 1964 & 1975 & Nomeado & Sim & & Sim & & Sim & 1 \\
\hline $\begin{array}{l}\text { Cyro V. da S. } \\
\text { Filho }\end{array}$ & Herval & 1966 & 1967 & Eleito & Sim & & Sim & & & 1 ou 5 \\
\hline $\begin{array}{l}\text { Luiz Lima de } \\
\text { Faria }\end{array}$ & Herval & 1964 & 1966 & Eleito & Sim & & Não & & & $\begin{array}{l}1,2,5 \\
\text { ou } 6\end{array}$ \\
\hline Walter N. Ferreira & Herval & 1969 & 1979 & Nomeado & Sim & Sim & Não & & Não & 5 ou 6 \\
\hline $\begin{array}{l}\text { Ottoni A. da } \\
\text { Silveira }\end{array}$ & Herval & 1979 & 1985 & Nomeado & Não & & Sim & & & $\begin{array}{l}1,3,5 \\
\text { ou } 7\end{array}$ \\
\hline José Luiz Ruschel & Horizontina & 1982 & 1985 & Nomeado & Não & & Sim & Sim & & $\begin{array}{l}1,3,5 \\
\text { ou } 7\end{array}$ \\
\hline Walter Bündchen & Horizontina & 1971 & 1975 & Nomeado & Sim & & & & & $\begin{array}{l}1,2,5 \\
\text { ou } 6\end{array}$ \\
\hline $\begin{array}{l}\text { Alfonso A } \\
\text { Lückemeyer }\end{array}$ & Horizontina & 1964 & 1971 & Nomeado & Sim & Não & & & & $\begin{array}{l}1,2,5 \\
\text { ou } 6\end{array}$ \\
\hline Irineu Colato & Horizontina & 1985 & 1982 & Nomeado & Não & Sim & Sim & Sim & Não & 5 \\
\hline $\begin{array}{l}\text { Nelson N. dos } \\
\text { Santos }\end{array}$ & Iraí & 1980 & 1983 & Interino & Não & Não & Não & Não & Não & 8 \\
\hline Ruy Born & Iraí & 1971 & 1979 & Nomeado & Não & Não & & Sim & & 3 ou 7 \\
\hline Urivalde Pigato & Iraí & 1964 & 1971 & Nomeado & Sim & Não & Sim & Não & Sim & 1 \\
\hline Juarez T. Boita & Iraí & 1979 & 1980 & Interino & Não & Não & Não & Não & Não & 8 \\
\hline
\end{tabular}




\begin{tabular}{|c|c|c|c|c|c|c|c|c|c|c|}
\hline Nome & Município & $\begin{array}{l}\text { Ano } \\
\text { início }\end{array}$ & $\begin{array}{l}\text { Ano } \\
\text { final }\end{array}$ & Entrada & $\begin{array}{l}\text { Eleito } \\
45 / 65\end{array}$ & $\begin{array}{l}\text { Bur. } \\
45 / 65\end{array}$ & $\begin{array}{l}\text { Eleito } \\
79 / 12\end{array}$ & $\begin{array}{l}\text { Bur. } \\
79 / 12\end{array}$ & $\begin{array}{l}\text { Fam. } \\
\text { Pol. }\end{array}$ & Rota \\
\hline Mario L. Flores & Itaqui & 1964 & 1974 & Nomeado & Sim & Não & Não & Sim & & 1 ou 5 \\
\hline $\begin{array}{l}\text { Alcides O. } \\
\text { Muraro }\end{array}$ & Itaqui & 1979 & 1985 & Nomeado & Sim & Não & Não & Sim & Sim & 1 \\
\hline Lydio C. da Silva & Itaqui & 1974 & 1979 & Nomeado & Não & Não & Não & Não & & 4 ou 8 \\
\hline Aldo F. Rosa & Jaguarão & 1979 & 1986 & Nomeado & & & Sim & & & $\begin{array}{l}1,3,5 \\
\text { ou } 7\end{array}$ \\
\hline $\begin{array}{l}\text { Claudionor B. } \\
\text { Dode }\end{array}$ & Jaguarão & 1975 & 1979 & Nomeado & & & Sim & & & $\begin{array}{l}1,3,5 \\
\text { ou } 7\end{array}$ \\
\hline $\begin{array}{l}\text { Rubens G. } \\
\text { Marques }\end{array}$ & Jaguarão & 1964 & 1969 & Nomeado & Não & Não & Não & Sim & Sim & 3 \\
\hline Darnô Fonseca & Jaguarão & 1969 & 1975 & Nomeado & & & & & & \\
\hline Jorge Dariva & Osório & 1975 & 1982 & Nomeado & Não & Não & Não & & & $\begin{array}{l}3,4,7 \\
\text { ou } 8\end{array}$ \\
\hline $\begin{array}{l}\text { Carlos F. D. } \\
\text { Azambuja }\end{array}$ & Osório & 1969 & 1975 & Nomeado & Não & Sim & Não & Não & & $\begin{array}{l}1,2,5 \\
\text { ou } 6\end{array}$ \\
\hline $\begin{array}{l}\text { Bruno } \\
\text { Niederauer }\end{array}$ & Osório & 1982 & 1985 & Nomeado & Não & Não & Não & Não & & 4 ou 8 \\
\hline $\begin{array}{l}\text { Otaviano B. } \\
\text { Noronha }\end{array}$ & Osório & 1982 & 1982 & Nomeado & Sim & Não & Sim & Não & & 1 ou 5 \\
\hline Telmo T. Flores & $\begin{array}{l}\text { Porto } \\
\text { Alegre }\end{array}$ & 1969 & 1975 & Nomeado & Não & Não & Sim & Sim & Não & 7 \\
\hline $\begin{array}{l}\text { Célio M. } \\
\text { Fernandes }\end{array}$ & $\begin{array}{l}\text { Porto } \\
\text { Alegre }\end{array}$ & 1965 & 1969 & Nomeado & Sim & & & & & $\begin{array}{l}1,2,5 \\
\text { ou } 6\end{array}$ \\
\hline Renato Souza & $\begin{array}{l}\text { Porto } \\
\text { Alegre }\end{array}$ & 1965 & 1965 & $\begin{array}{l}\text { Eleito pela } \\
\mathrm{CV}\end{array}$ & Sim & Não & Não & Não & Não & 6 \\
\hline $\begin{array}{l}\text { Guilherme S. } \\
\text { Villela }\end{array}$ & $\begin{array}{l}\text { Porto } \\
\text { Alegre }\end{array}$ & 1975 & 1983 & Nomeado & Não & Sim & Sim & Sim & & 1 ou 5 \\
\hline $\begin{array}{l}\text { João Antônio } \\
\text { Dib }\end{array}$ & $\begin{array}{l}\text { Porto } \\
\text { Alegre }\end{array}$ & 1983 & 1986 & Nomeado & Sim & Sim & Sim & Sim & Não & 5 \\
\hline $\begin{array}{l}\text { Célio M. } \\
\text { Fernandes }\end{array}$ & $\begin{array}{l}\text { Porto } \\
\text { Alegre }\end{array}$ & 1964 & 1965 & Interino & Não & Não & Não & Não & Não & 8 \\
\hline $\begin{array}{l}\text { Waldemar } \\
\text { Bordim }\end{array}$ & $\begin{array}{l}\text { Porto } \\
\text { Lucena }\end{array}$ & 1966 & 1969 & Eleito & Não & & Sim & & & $\begin{array}{l}1,3,5 \\
\text { ou } 7\end{array}$ \\
\hline $\begin{array}{l}\text { Zoé de Souza } \\
\text { Garcia }\end{array}$ & $\begin{array}{l}\text { Porto } \\
\text { Lucena }\end{array}$ & 1969 & 1975 & Nomeado & & & & & & \\
\hline $\begin{array}{l}\text { Eugenio R. } \\
\text { Werlang }\end{array}$ & $\begin{array}{l}\text { Porto } \\
\text { Lucena }\end{array}$ & 1981 & 1985 & Nomeado & Não & Sim & Sim & Sim & Não & 5 \\
\hline $\begin{array}{l}\text { Clemente } \\
\text { Santignon }\end{array}$ & $\begin{array}{l}\text { Porto } \\
\text { Lucena }\end{array}$ & 1975 & 1981 & Nomeado & Não & Não & Sim & Sim & Sim & 3 \\
\hline Hugo Feier & $\begin{array}{l}\text { Porto } \\
\text { Xavier }\end{array}$ & 1966 & 1976 & Nomeado & Sim & Não & Não & Não & Não & 6 \\
\hline
\end{tabular}




\begin{tabular}{|c|c|c|c|c|c|c|c|c|c|c|}
\hline Nome & Município & $\begin{array}{l}\text { Ano } \\
\text { início }\end{array}$ & $\begin{array}{l}\text { Ano } \\
\text { final }\end{array}$ & Entrada & $\begin{array}{l}\text { Eleito } \\
45 / 65\end{array}$ & $\begin{array}{l}\text { Bur. } \\
45 / 65\end{array}$ & $\begin{array}{l}\text { Eleito } \\
79 / 12\end{array}$ & $\begin{array}{l}\text { Bur. } \\
79 / 12\end{array}$ & $\begin{array}{l}\text { Fam. } \\
\text { Pol. }\end{array}$ & Rota \\
\hline Ouvidio Kaiser & $\begin{array}{l}\text { Porto } \\
\text { Xavier }\end{array}$ & 1979 & 1985 & Nomeado & Não & Não & Não & Sim & Sim & 3 \\
\hline $\begin{array}{l}\text { Paulo Martim } \\
\text { Engers }\end{array}$ & $\begin{array}{l}\text { Porto } \\
\text { Xavier }\end{array}$ & 1976 & 1979 & Nomeado & & & & & Sim & $\begin{array}{l}1,2,3 \\
\text { ou } 4\end{array}$ \\
\hline Juarez C. Gomes & Quaraí & 1979 & 1985 & Nomeado & Não & Sim & Sim & Não & Não & 5 \\
\hline $\begin{array}{l}\text { Heraclides S. } \\
\text { Helena }\end{array}$ & Quaraí & 1964 & 1978 & Nomeado & Sim & Não & & & Sim & 1 ou 2 \\
\hline $\begin{array}{l}\text { Abel Abreu } \\
\text { Dourado }\end{array}$ & Rio Grande & 1981 & 1985 & Nomeado & Não & Não & Sim & Sim & Não & 7 \\
\hline $\begin{array}{l}\text { Gen. Armando } \\
\text { Cattani }\end{array}$ & Rio Grande & 1966 & 1969 & Nomeado & Não & Sim & Não & Não & Não & 6 \\
\hline $\begin{array}{l}\text { Irio Figueira } \\
\text { Sucena }\end{array}$ & Rio Grande & 1978 & 1978 & Interino & & & & Sim & & $\begin{array}{l}1,3,5 \\
\text { ou } 7\end{array}$ \\
\hline $\begin{array}{l}\text { Cap. Martiniano } \\
\text { F. de Oliveira }\end{array}$ & Rio Grande & 1964 & 1966 & Nomeado & Não & Não & & & Não & 7 ou 8 \\
\hline $\begin{array}{l}\text { Ten. Cel. Cid S } \\
\text { Vieira }\end{array}$ & Rio Grande & 1969 & 1975 & Nomeado & Não & Não & Não & Sim & Não & 7 \\
\hline Rubens E. Corrêa & Rio Grande & 1975 & 1978 & Nomeado & Não & Não & Sim & Não & Sim & 3 \\
\hline $\begin{array}{l}\text { Adair Vicente } \\
\text { Brum }\end{array}$ & $\begin{array}{l}\text { Roque } \\
\text { Gonzales }\end{array}$ & 1975 & 1981 & Nomeado & Não & Não & Sim & Sim & Sim & 3 \\
\hline José B. de Brum & $\begin{array}{l}\text { Roque } \\
\text { Gonzales }\end{array}$ & 1981 & 1983 & Nomeado & Não & Não & Não & Não & Sim & 4 \\
\hline $\begin{array}{l}\text { Leocadio O. } \\
\text { Welter }\end{array}$ & $\begin{array}{l}\text { Roque } \\
\text { Gonzales }\end{array}$ & 1969 & 1975 & Eleito & & & Não & Não & Não & 6 ou 8 \\
\hline José D. Bordim & $\begin{array}{l}\text { Roque } \\
\text { Gonzales }\end{array}$ & 1969 & 1975 & Eleito & Não & Não & Não & Não & Não & 8 \\
\hline $\begin{array}{l}\text { Arão de S. } \\
\text { Antunes }\end{array}$ & $\begin{array}{l}\text { Roque } \\
\text { Gonzales }\end{array}$ & 1966 & 1969 & Nomeado & Não & Sim & Não & Não & Não & 6 \\
\hline $\begin{array}{l}\text { Pedro V. } 0 . \\
\text { Marques }\end{array}$ & $\begin{array}{l}\text { Roque } \\
\text { Gonzales }\end{array}$ & 1983 & 1985 & Nomeado & Não & Sim & Não & Sim & Não & 5 \\
\hline Hugo G. Soares & $\begin{array}{l}\text { Sta. Vit. } \\
\text { Palmar }\end{array}$ & 1979 & 1985 & Nomeado & Não & Não & Não & Não & Não & 8 \\
\hline $\begin{array}{l}\text { Cel. José Menna B. } \\
\text { Lamper }\end{array}$ & $\begin{array}{l}\text { Sta. Vit. } \\
\text { Palmar }\end{array}$ & 1969 & 1975 & Nomeado & & & & & & \\
\hline $\begin{array}{l}\text { João de O. } \\
\text { Rodrigues }\end{array}$ & $\begin{array}{l}\text { Sta. Vit. } \\
\text { Palmar }\end{array}$ & 1964 & 1969 & Eleito & Sim & Não & Não & Não & Não & 6 \\
\hline $\begin{array}{l}\text { Dr. Aury de } \\
\text { Oliveira }\end{array}$ & $\begin{array}{l}\text { Sta. Vit. } \\
\text { Palmar }\end{array}$ & 1976 & 1979 & Nomeado & & & & & & \\
\hline $\begin{array}{l}\text { Milton Linn } \\
\text { Molinos }\end{array}$ & $\begin{array}{l}\text { Santana do } \\
\text { Livramento }\end{array}$ & 1964 & 1969 & Eleito & Sim & Não & Não & Não & Não & 6 \\
\hline
\end{tabular}




\begin{tabular}{|c|c|c|c|c|c|c|c|c|c|c|}
\hline Nome & Município & $\begin{array}{l}\text { Ano } \\
\text { início }\end{array}$ & $\begin{array}{l}\text { Ano } \\
\text { final }\end{array}$ & Entrada & $\begin{array}{l}\text { Eleito } \\
45 / 65\end{array}$ & $\begin{array}{l}\text { Bur. } \\
45 / 65\end{array}$ & $\begin{array}{l}\text { Eleito } \\
79 / 12\end{array}$ & $\begin{array}{l}\text { Bur. } \\
79 / 12\end{array}$ & $\begin{array}{l}\text { Fam. } \\
\text { Pol. }\end{array}$ & Rota \\
\hline $\begin{array}{l}\text { Guilherme B. } \\
\text { Costa }\end{array}$ & $\begin{array}{l}\text { Santana do } \\
\text { Livramento }\end{array}$ & 1975 & 1985 & Nomeado & Não & Não & Sim & Não & Não & 7 \\
\hline Ney C. Campos & $\begin{array}{l}\text { Santana do } \\
\text { Livramento }\end{array}$ & 1971 & 1975 & Nomeado & Sim & & & & & $\begin{array}{l}1,2,5 \\
\text { ou } 6\end{array}$ \\
\hline $\begin{array}{l}\text { General Antônio } \\
\text { M. Borges }\end{array}$ & $\begin{array}{l}\text { Santana do } \\
\text { Livramento }\end{array}$ & 1969 & 1971 & Nomeado & & & & & Não & $\begin{array}{l}5,6,7 \\
\text { ou } 8\end{array}$ \\
\hline $\begin{array}{l}\text { José Pereira } \\
\text { Alvarez }\end{array}$ & São Borja & 1966 & 1974 & Nomeado & Não & Não & Sim & Sim & Sim & 3 \\
\hline $\begin{array}{l}\text { Bel. Arneldo } \\
\text { Matter }\end{array}$ & São Borja & 1984 & 1985 & Nomeado & Não & Não & Não & Não & Não & 8 \\
\hline $\begin{array}{l}\text { João Carlos M } \\
\text { Escobar }\end{array}$ & São Borja & 1974 & 1979 & Nomeado & Sim & Não & Não & Não & Sim & 2 \\
\hline $\begin{array}{l}\text { Hildebrando A. } \\
\text { Guimarães }\end{array}$ & São Borja & 1982 & 1984 & Nomeado & & & & & & \\
\hline $\begin{array}{l}\text { Salvador L. P } \\
\text { Alvarez }\end{array}$ & São Borja & 1979 & 1982 & Nomeado & Não & Não & Não & Não & Sim & 4 \\
\hline Rudi Weber & $\begin{array}{l}\text { São } \\
\text { Nicolau }\end{array}$ & 1979 & 1985 & Nomeado & Não & Não & Sim & Sim & Não & 7 \\
\hline $\begin{array}{l}\text { Sady Martins } \\
\text { Portela }\end{array}$ & $\begin{array}{l}\text { São } \\
\text { Nicolau }\end{array}$ & 1966 & 1969 & Nomeado & Não & & & & Não & $\begin{array}{l}5,6,7 \\
\text { ou } 8\end{array}$ \\
\hline $\begin{array}{l}\text { Vicente Miguel } \\
\text { Soares }\end{array}$ & $\begin{array}{l}\text { São } \\
\text { Nicolau }\end{array}$ & 1969 & 1971 & Nomeado & Não & Sim & & & Não & 5 ou 6 \\
\hline $\begin{array}{l}\text { Ademar R. da } \\
\text { Silveira }\end{array}$ & $\begin{array}{l}\text { São } \\
\text { Nicolau }\end{array}$ & 1971 & 1975 & Nomeado & & & & & & \\
\hline Ercy G. de Oliveira & $\begin{array}{l}\text { São } \\
\text { Nicolau }\end{array}$ & 1975 & 1979 & Nomeado & Não & Não & Não & Não & Sim & 4 \\
\hline $\begin{array}{l}\text { Alcides José } \\
\text { Salamoni }\end{array}$ & $\begin{array}{l}\text { Tenente } \\
\text { Portela }\end{array}$ & 1964 & 1971 & $\begin{array}{l}\text { Eleito, } \\
\text { depois } \\
\text { nomeado }\end{array}$ & Não & Não & Não & Não & Sim & 4 \\
\hline $\begin{array}{l}\text { Arlindo } \\
\text { Schwantes }\end{array}$ & $\begin{array}{l}\text { Tenente } \\
\text { Portela }\end{array}$ & 1972 & 1975 & Nomeado & Não & Não & Não & Não & Sim & 4 \\
\hline $\begin{array}{l}\text { Teobaldo } \\
\text { Willi Pilger } \\
\text { (vice-Prefeito) }\end{array}$ & $\begin{array}{l}\text { Tenente } \\
\text { Portela }\end{array}$ & 1964 & 1969 & $\begin{array}{l}\text { Eleito, } \\
\text { depois } \\
\text { nomeado }\end{array}$ & Não & Não & Não & Não & Sim & 4 \\
\hline Israel Capellari & $\begin{array}{l}\text { Tenente } \\
\text { Portela }\end{array}$ & 1976 & 1981 & Nomeado & Não & Não & Não & Não & Sim & 4 \\
\hline Lúcio A. Motta & $\begin{array}{l}\text { Tenente } \\
\text { Portela }\end{array}$ & 1981 & 1985 & Nomeado & Não & Sim & Sim & Sim & Sim & 1 \\
\hline $\begin{array}{l}\text { General Luiz } \\
\text { Dêntice }\end{array}$ & Tramandaí & 1967 & 1971 & Nomeado & & & & Não & & \\
\hline Elói Braz Sessim & Tramandaí & 1979 & 1983 & Nomeado & Não & Não & Sim & Não & Sim & 3 \\
\hline
\end{tabular}




\begin{tabular}{|c|c|c|c|c|c|c|c|c|c|c|}
\hline Nome & Município & $\begin{array}{l}\text { Ano } \\
\text { início }\end{array}$ & $\begin{array}{l}\text { Ano } \\
\text { final }\end{array}$ & Entrada & $\begin{array}{l}\text { Eleito } \\
45 / 65\end{array}$ & $\begin{array}{l}\text { Bur. } \\
45 / 65\end{array}$ & $\begin{array}{l}\text { Eleito } \\
79 / 12\end{array}$ & $\begin{array}{l}\text { Bur. } \\
79 / 12\end{array}$ & $\begin{array}{l}\text { Fam. } \\
\text { Pol. }\end{array}$ & Rota \\
\hline $\begin{array}{l}\text { Onil X. dos } \\
\text { Santos }\end{array}$ & Tramandaí & 1971 & 1973 & Nomeado & Sim & Não & Não & Não & & 2 ou 6 \\
\hline $\begin{array}{l}\text { Egídio Sarconi } \\
\text { Neves }\end{array}$ & Tramandaí & 1979 & 1979 & Interino & Não & Não & Não & Não & & 4 ou 8 \\
\hline Aury De Oliveira & Tramandaí & 1973 & 1975 & Nomeado & Não & Não & Não & Não & & 4 ou 8 \\
\hline Elói Braz Sessim & Tramandaí & 1978 & 1979 & Interino & Não & Não & Sim & Não & Sim & 3 \\
\hline $\begin{array}{l}\text { João Carlos } \\
\text { Wender }\end{array}$ & Tramandaí & 1983 & 1985 & Nomeado & Não & Não & Sim & Não & & 3 ou 7 \\
\hline $\begin{array}{l}\text { Décio G. De } \\
\text { Azevedo }\end{array}$ & Tramandaí & 1975 & 1978 & Nomeado & Não & & & Não & & \\
\hline $\begin{array}{l}\text { Renato J. } \\
\text { Oppermann }\end{array}$ & Tres Passos & 1979 & 1986 & Nomeado & Não & Não & Não & Não & & 4 ou 8 \\
\hline Egon Lautert & Tres Passos & 1975 & 1979 & Nomeado & Não & Não & Não & Não & & 4 ou 8 \\
\hline Egon J. Goelzer & Tres Passos & 1969 & 1975 & Nomeado & Sim & Não & Não & Não & & 2 ou 6 \\
\hline Alcides Braun & Tres Passos & 1964 & 1969 & $\begin{array}{l}\text { Eleito, } \\
\text { depois } \\
\text { nomeado }\end{array}$ & Sim & Sim & Não & Não & & 2 ou 6 \\
\hline $\begin{array}{l}\text { Ermindo C. } \\
\text { Schwerz }\end{array}$ & Tucunduva & 1970 & 1973 & Nomeado & Sim & Não & Não & Sim & Não & 5 \\
\hline João Puhl & Tucunduva & 1963 & 1970 & $\begin{array}{l}\text { Eleito, } \\
\text { depois } \\
\text { nomeado }\end{array}$ & Sim & Não & Não & Não & Não & 6 \\
\hline Artur Fronza & Tucunduva & 1979 & 1982 & $\begin{array}{l}\text { Eleito pela } \\
\mathrm{CV}\end{array}$ & Sim & Não & Não & & Sim & 1 ou 2 \\
\hline João Puhl & Tucunduva & 1973 & 1979 & Nomeado & Sim & Não & Não & Não & Não & 6 \\
\hline Nerci Camera & Tucunduva & 1983 & 1985 & Nomeado & Não & Não & Sim & Sim & Não & 7 \\
\hline Aquiles Turra & Tuparendi & 1964 & 1971 & Eleito & Sim & Não & Não & Não & Não & 6 \\
\hline José A. Grando & Tuparendi & 1983 & 1985 & Nomeado & Não & Não & Sim & Sim & Sim & 3 \\
\hline Luiz Mattiazzi & Tuparendi & 1979 & 1983 & Nomeado & Não & Não & Não & Não & Não & 8 \\
\hline $\begin{array}{l}\text { Candido } \\
\text { Giordani }\end{array}$ & Tuparendi & 1971 & 1979 & Nomeado & Não & Não & Não & Sim & Não & 7 \\
\hline $\begin{array}{l}\text { Francisco F. S } \\
\text { Pedroso }\end{array}$ & Uruguaiana & 1985 & 1985 & Interino & Não & Não & Sim & & & 3 ou 7 \\
\hline $\begin{array}{l}\text { Francisco C. S. de } \\
\text { Barros Coelho }\end{array}$ & Uruguaiana & 1979 & 1980 & Nomeado & Não & Sim & & & Sim & 1 ou 2 \\
\hline $\begin{array}{l}\text { Antonio A. B. } \\
\text { Carus }\end{array}$ & Uruguaiana & 1976 & 1979 & Nomeado & Não & Sim & Sim & Sim & Não & 5 \\
\hline Newton L. Ulrich & Uruguaiana & 1976 & 1976 & Interino & & & & & & \\
\hline Homero Tarragó & Uruguaiana & 1964 & 1968 & Eleito & Sim & Sim & Não & Não & Sim & 2 \\
\hline
\end{tabular}


T\&P O regime civil-militar e a política local: uma proposta de tipologia para análise de recrutamento e padrões de carreira de prefeitos nomeados no Rio Grande do Sul

\begin{tabular}{|c|c|c|c|c|c|c|c|c|c|c|}
\hline Nome & Município & $\begin{array}{l}\text { Ano } \\
\text { início }\end{array}$ & $\begin{array}{l}\text { Ano } \\
\text { final }\end{array}$ & Entrada & $\begin{array}{l}\text { Eleito } \\
45 / 65\end{array}$ & $\begin{array}{l}\text { Bur. } \\
45 / 65\end{array}$ & $\begin{array}{l}\text { Eleito } \\
79 / 12\end{array}$ & $\begin{array}{l}\text { Bur. } \\
79 / 12\end{array}$ & $\begin{array}{l}\text { Fam. } \\
\text { Pol. }\end{array}$ & Rota \\
\hline $\begin{array}{l}\text { Cel. Gilberto O. M. } \\
\text { Schmitt }\end{array}$ & Uruguaiana & 1968 & 1976 & Nomeado & & & & & & \\
\hline $\begin{array}{l}\text { Antonio A. B. } \\
\text { Carus }\end{array}$ & Uruguaiana & 1980 & 1985 & Nomeado & Não & Sim & Sim & Sim & Não & 5 \\
\hline Carlos Dalcin & $\begin{array}{l}\text { Vicente } \\
\text { Dutra }\end{array}$ & 1971 & 1975 & Nomeado & & & Não & & & \\
\hline $\begin{array}{l}\text { Rudi Ervino } \\
\text { Kirchoff }\end{array}$ & $\begin{array}{l}\text { Vicente } \\
\text { Dutra }\end{array}$ & 1969 & 1979 & Interino & Não & Não & Não & & & $\begin{array}{l}3,4,7 \\
\text { ou } 8\end{array}$ \\
\hline $\begin{array}{l}\text { Osmar José da } \\
\text { Silva }\end{array}$ & $\begin{array}{l}\text { Vicente } \\
\text { Dutra }\end{array}$ & 1979 & 1982 & Interino & Não & Não & Sim & & & 3 ou 7 \\
\hline $\begin{array}{l}\text { Emílio C. } \\
\text { Pastório }\end{array}$ & $\begin{array}{l}\text { Vicente } \\
\text { Dutra }\end{array}$ & 1966 & 1967 & Nomeado & & & & & & \\
\hline Sérgio E. Dal Forno & $\begin{array}{l}\text { Vicente } \\
\text { Dutra }\end{array}$ & 1975 & 1977 & Interino & & & Sim & & & $\begin{array}{l}1,3,5 \\
\text { ou } 7\end{array}$ \\
\hline Augusto Fabris & $\begin{array}{l}\text { Vicente } \\
\text { Dutra }\end{array}$ & 1969 & 1971 & Interino & & & & & & \\
\hline $\begin{array}{l}\text { Cel. Ápio P. De } \\
\text { Vasconcelos }\end{array}$ & $\begin{array}{l}\text { Vicente } \\
\text { Dutra }\end{array}$ & 1969 & 1971 & Nomeado & & & & & & \\
\hline
\end{tabular}

Recebido 4/11/2014

Aceito: 16/12/2014 